\title{
THE REPRESENTATION OF MUSLIMS IN RUDYARD KIPLING'S SHORT STORIES A Postcolonial Perspective
}

\section{Mugijatna}

Sebelas Maret University, Surakarta, Indonesia

email:ykesl_si@@yahoo.com

\section{Abstract}

This article studies Rudyard Kipling's four short stories, "Wee Willie Winkie", "The Recrudescence of Imray", "The Story of Mubammad Din", and "Without Benefit of Clergy". The purposes of this research are to describe the representation of Muslims in the four short stories and to describe how the representation of Muslims in the four short stories represents British colonization in India. In this paper, I employs textual study methodology using narrative analysis, binary-opposition analysis, and metaphorical iconicity analysis. The conclusion is that the representation of Muslims in the four short stories ranges from perceiving Muslims as bed men living in bills and forest to perceiving Muslims as the slaves of the British. In all the representations, the British is not presented as an oppressor, instead as a benevolent master. It is a metaphor of Kipling's firm belief that the British were helping to civilize and educate a previously "savage" people. It disregards the fact that British colonization over India had ruined Islamic empire in India under Mogul Court sovereignty and ruined Indian economy and society organization.

Penelitian ini mengkaji empat cerita pendek Rudyard Kipling, "Wee Willie Winkie", "The Recrudescence of Imray", "The Story of Mubammad Din", dan "Without Benefit of Clergy". Adapun tujuan daripenelitian ini adalah mendeskripsikan representasi Muslim dalam empat cerita pendek. tersebut dan mendeskripsikan bagaimana gambaran tersebut merepresentasikan kolonisasi Inggris atas India. Metode yang digunakan adalah metodologi kajian tekstual dengan analisis naratif, analisis oposisi-biner, dan analisis ikonositas metaforis. 
M. Mugijatna

Kesimpulannya adalah bahwa representasi Muslim dalam empat cerita pendek tersebut merentang mulai dari muslim sebagai orang-orang jahat yang hidup di gunung dan hutan hingga sebagai budak orang Inggris. Dalam represestasi itu orang Inggris tidak pernah digambarkan sebagai penindas. Representasi ini merupakan metafora kepercayaan Rudyard Kipling bahwa kehadiran Inggris di India adalah untuk mengadabk an dan mendidik orang India yang semula liar. Representasi ini mengabaikan kenyataan bahwa kehadiran Inggris di India telah menghancurkan imperium Islam di India di bawah kedaulatan Istana Mogul dan meruntubkan ekonomi dan susunan masyarakat India.]

Keywords: Rudyard Kipling, colonial stories, British imperialism, India muslim.

\section{A. Introduction}

George W. Bush's war on terorism after the 9/11 attack on WTC has opened up re-colonization ${ }^{1}$ over Muslim countries. United States invaded Afghanistan and then Iraq, using the same justification used by East India Company (EIC) when invading new territories. ${ }^{2}$ Once again the East, in particular Islam, is presented as such in order to justify the subjugation of Islam. If in old days Muhammad had been described as a liar and Islam had been described as heretic, ${ }^{3}$ now Muhammad is described as a terrorist and Islam is described as a religion that fosters terrorism. "The image of a Saracen with a scimitar in one hand and the Quran in the other is a staple of orientalism past and present". ${ }^{4}$ So far, attack on terrorism has been synonymous to attack on Islam; the de-radicalization program for Muslims in Indonesia betrays the identification of Muslims with terrorists. " "Thus, Islam emerges in contrast to Christendom in the formation of pre-modern identification of Europe, and re-emerges as

${ }^{1}$ S. Sayyid, "Empire, Islam and the Postcolonial", in MnM Working Paper No. 9 (Australia: University of South Australia, 2012), p. 14, http://www.unisa.edu.au/ Documents/EASS/MnM/working-papers/sayyid-empaire-islam-postcolonial.pdf, accessed 1 Jun 2014.

${ }^{2}$ Karl Marx, "Anglo-Persian War", in Friedrich Engels and Karl Marx, On Colonialism (Moscow: Foreign Languages Publishing House, 1968), p. 91.

${ }^{3}$ Edward W. Said, Orientalisme, trans. by Asep Hikmat (Bandung: Penerbit Pustaka, 1978), p. 85.

${ }^{4}$ Sayyid, "Empire, Islam", p. 5.

${ }^{5}$ Majelis Ulama Indonesia (MUI) Kota Surakarta, Kritik Evaluasi \& Dekonstruksi Gerakan Deradikalisasi Aqidah Muslimin di Indonesia (Surakarta: Al Maktab Publication, 2011). 
The Representation of Muslims in Rudyard Kipling's Short Stories one major opponent of European colonialism, and now it appears as the cosmological enemy of the war on terror". 6

In order to understand better the Western's re-colonization over Islam at present time, we need to recollect Western's colonization over Islam in the past. It "may be particularly relevant when postcolonial criticism addresses Western perceptions of Islam and Muslims".7 Western's perception of Islam and Muslims as well as Western's colonization over Islam in the past could be traced back through literary works produced during the colonization. Sociologically, literature could be treated as a "social document, as assumed picture of social reality". 8 "Used as social document, literature can be made to yield the outlines of social history"?

Many English writers wrote novels, short stories and poems about East people as backward, uncultured and cruel people. This kind of representation is to justify the presence of the West in the East countries, that is, to accomplish the so-called White Men's Mission to civilize Eastern people.

Kipling, one of the writers, is regarded as an advocate of British imperialism in India. Moosavinia describes Kim, one of Kipling's novels, as follows: "The narrative voice in the novel treats the Oriental as an inferior being. The oriental tells lies, takes commission, is accustomed to disorder, and has no sense of time". ${ }^{10}$ Inna Lindgren in her article, "Plain Tales from the Hills as Emergent Literature," discuses how Plain Tales from the Hills, Kipling's first anthology of short stories, present the native Indian as inferior beings: "This is where the book is emergent AngloIndian literature at its most aggressive, through most strongly underlying a perceived Anglo-Indian superiority in matters Indian". ${ }^{11}$ Even, in "The Story of Muhammad Din, the narrator presents Muhammad Din as "less

${ }^{6}$ Sayyid, "Empire, Islam”, p. 16.

${ }^{7}$ Monika Albrecht, "Postcolonialism, Islam, and Contemporary Germany", Transit, vol. 7, no. 1 (2011), p. 1.

${ }^{8}$ Rene Wellek and Austin Warren, Theory of Literature (New York: Harcourt, Brace \& World Inc, 1956), p. 102.

${ }^{9}$ Ibid., p. 103.

${ }^{10}$ Rahim Moosavinia, "Texts and Politics: Postcolonial Revaluations of Two British Classics", Journal of Teaching Language Skills (JTLS), vol. 3, no. 3 (2011), p. 69.

${ }^{11}$ Inna Lindgrén, "Plain Tales from the Hills as Emergent Literature", Nordic Journal of English Studies, vol. 6, no. 2 (2007), p. 94. 


\section{Mugijatna}

human". ${ }^{12}$ That is why, as revealed by Benita Parry, "T.S. Eliot's praise for Kipling's vision of imperial responsibility in a 1941 essay met with opposition from prominent writers and critics". ${ }^{13}$ In the article, "The Content and Discontents of Kipling's Imperialism," Benita Parry writes that:

Kipling's writings moved empire from the margins of English fiction to its centre without interrogating the official metropolitan culture. In cataloguing devotion to dominant beliefs in Something of Myself, an autobiography written in old age, he had no occasion to repent youthful indiscretions of opinion. ${ }^{14}$

In this article I study Rudyard Kipling's four short stories, "Wee Willie Winkie," "The Recrudescence of Imray,"15 "The Story of Muhammad Din," and "Without Benefit of Clergy". The four short stories were purposively selected based on the content of the short stories. "We Willie Winkie" contains a story of an English Child, a son of a commandant of an English Garrison, protecting an English girl from native (muslims) people. "The Recrudescence of Imray" contains the story of a murder done by a Muslim (Mohammedan), motivated by superstitious belief. "The Story of Muhammad Din" contains the story of a Muslim child in his interaction with his Sabib. "Without the Benefit of Clergy" contains a story of a Muslim woman as a wife of an English man. The four short stories present exemplary perceptions of English imperialist on Muslims (and Islam).

The purposes of this study are to describe the representation of Muslims in the four short stories and to describe how the representation of Muslims in the four short stories represents British colonization in India. In accordance with the focus, the proper methodology of this research is textual methodology.

All the data are in the forms of words and sentences, collected using "content analysis", a technique used to collect data from "written

12 "A Postcolonial Reading of Kipling's Muhammad Din", https:/ / sites.google. $\mathrm{com} / \mathrm{site} / \mathrm{jimmyastacio} /$ apostcolonialreadingofkipling's $\% 22$ muhammad, accessed 26 May 2014.

${ }^{13}$ Benita Parry, "The Content and Discontents of Kipling's Imperialism", in Space and Place: Theories of Identity and Location, ed. by Erica Carter, James Donald, and Judith Squires (London: Lawrence \& Wishart, 1993), p. 4.

${ }^{14}$ Ibid., pp. 51-2.

15 This short story is also called "The Return of Imray".

${ }^{16}$ It as an address to European (English) master by Indians during colonial time; it means "sir", or "master". 
The Representation of Muslims in Rudyard Kipling's Short Stories materials (textbooks, novels, newspapers)". ${ }^{17}$ The "content analysis" was conducted in qualitative fashion: I read the stories closely and made notes on the words and sentences having something to do with the purposes of this research.

The frame of analysis is narrative analysis combined with binaryopposition analysis and metaphorical iconicity analysis. The theories can be explained briefly as follows. "A narrative is a structured sequence of events in time," while "Events are the basic units of a story". ${ }^{18}$ Narrative analysis is aimed at constructing the plot of the short stories. Binaryopposition is two oppositional related categories. ${ }^{19}$ Binary-opposition analysis is to compare the representation of Muslim characters with British characters in the short stories. Metaphorical iconicity, as C. S. Peirce puts it, is "sign which represents representative character of a representament by representing a parallelism in something else", ${ }^{20}$ Metaphorical iconicity analysis is, then, to describe the similarity between the world in the short stories and the real world experienced by Rudyard Kipling.

\section{B. British Colonization in India}

East India Company (EIC) started its first voyage in 1601 to take their agents in Sumatra and Java, but Dutch and Portuguese traders who arrived earlier resisted them. They turned their eyes on India which they perceived would be more favorable; the expedition to India was led by Captain William Hawkins and arrived at the port city of Surat in 1608. Due to Portuguese intrigue who had settled in India, Captain William Hawkins was not permitted to establish a trading post in Surat, yet he was allowed to enter the city and changed goods. The second voyage in 1612 was led by Captain Best with his ship, the Red Dragon, and the Portuguese fleet which tried to intercept the ship in the harbor of Port Surat was repelled. The Company's ship spectacular won over Portuguese fleet made it favorable to the Mogul Court. ${ }^{21}$ The Company

${ }^{17}$ Catherine Marshall and Gretchen B. Rossman, Designing Qualitative Research, 2nd ed. (California: Sage Publications, 1995), p. 85.

18 Tony Thwaites, Lloyd Davis, and Warwick Mules, Tools for Cultural Studies: an Introduction (Melbourne: Macmillan Education Australia PTY LTD, 1995), pp. 118-31.

${ }^{19}$ John Fiske, Cultural and Communication Studies, 3rd ed., ed. by Idi Subandy Ibrahim, trans. by Yusal Iriantara (Yogyakarta: Jalasutra, 2006), p. 161.

${ }^{20}$ Winfried Nöth, Handbook of Semiotics (Indiana Polis: Indiana University Press, 1995), p. 133.

${ }^{21}$ Mughal is another spelling for Mogul 


\section{Mugijatna}

was granted a license to establish trading post in Surat and the EIC got its first grasp in the subcontinent. In 1639 the company built a fort in Madras, in 1661 acquired Bombay from King Charles II who acquired it from his Portugal wife, and in 1690 the company built a settlement in Port William in northeastern city of Calcutta. ${ }^{22}$

So far, the Company had only done business with non-interference policy. The change occurred when, on the one hand, in 1702 the Company and a newly chartered company claiming monopoly trade in East India were merged into a single company. This merge made the Company more secured and had more energy. Commenting on this merge Karl Marx says that "The true commencement of the East India Company cannot be dated from a more remote epoch than the year 1702, when the different societies, claiming the monopoly of the East India trade, united together in one single Company". ${ }^{23}$ Prior to 1702, the Company was often in danger. On the other hand, following the death of Aurungzeb in 1707 Mogul Court deteriorated and small-local states emerged along the costal line. The nawabs ${ }^{24}$ of the small-local states contended to each other and the contenders like to ask for support from Europeans for their ambition. Siraj-ud-daula, a key nawab, supported by Joseph-Francois Dupleix, the governor of "Compagnie des Indies Orientales", a French trade company in India, captured 146 British citizens and 123 of them were perished overnight; this event came to be known as "Black Hole of Calcutta". Led by Robert Clive, the Company forces retaliated swiftly and quickly regained control of their possession in Calcutta. ${ }^{25}$ This marked the end of peaceful non-intervention policy of the Company, because the Company had only two choices, fight or die. ${ }^{26}$ By the end of $18^{\text {th }}$ century, "the British had established a military dominance that would enable them in the next fifty years to subdue all the remaining Indian states of any consequence, either conquering them or forcing their rulers to become subordinate allies". ${ }^{27}$ Quoting an English writer, Karl Marx says that in

${ }^{22}$ Ryan Brown, "The British Empire in India" (Ohio: Ashbrook-Ashland University, 2010), p. 18, http://ashbrook.org/wp-content/uploads/2012/06/2010Brown.pdf.

${ }^{23}$ Karl Marx, "The East India Company - Its History and Results", in Karl Marx and Friedrich Engels, On Colonialism (Moscow: Progress, 1968), p. 44.

${ }^{24}$ Vassals of Mogul Court.

${ }^{25}$ Brown, "The British Empire in India", p. 22.

${ }^{26}$ Ibid.

${ }^{27}$ Peter Marshall, "The British Presence in India in the 18th Century", BBC, http://www.bbc.co.uk/history/british/empire_seapower/east_india_01.shtml\#top, 
subjugating the remaining Indian Princes EIC followed Roman politics system, "a system of fattening allies, as we fatten oxen, till they were worthy of being devoured". ${ }^{28}$

Entering $19^{\text {th }}$ century, EIC was slowly shifting from merely a trading company into an administrative government. Trade became less important and tax collection became more important. Moreover, in 1813 and 1833 British government passed acts that ended the privileged monopoly rights for the Company chartered in twelfth century. Following the mutiny in the army by the Sepoys (1857-1858) direct involvement of British government became inevitable. The mutiny was triggered by a reformation policy launched by Governor General Lord Dalhousie (18481856). The Dalhousie's reformation agenda coincided with missionary activities. The rumour that the new cartridge for the army was greased with animal fat offended both Hindus and Muslims: cow fat offended Hindus and pig fat offended Muslims. Hindu and Muslim Sepoys didn't want to touch the new cartridge and this break on the discipline increased into mutiny. The Company under Dalhousie's successor, Lord Canning, should struggle for survival. Eventually, Lord Canning could successfully restored peace on July 8, 1858. The mutiny prompted Queen Victoria to put India under direct control of British crown. In 1858 an act was passed to end EIC to be replaced by British Raj. ${ }^{29}$

In $20^{\text {th }}$ century British Empire all over the world dissolved. In India, as in other British Empire, as noted by Young, it resulted from many elements.

Many elements were similar to other liberation movements: the beginning of a constitutional reform movement with the founding of the Indian National Congress in 1885, the establishment of the Muslim League in 1906 and the impact of the Khilafat movement and other forms of pan-Islamism, the grasping of the radical alternative posited by the Bolshevik revolution in 1917 and the development of a Communist Party linked to the International and the opportunistic exertion of maximum pressure after the defeat of the imperial powers by Japan during the Second World War. ${ }^{30}$

accessed 26 May 2014.

${ }^{28}$ Marx, "The East India Company", p. 73. Change Alley is a street in London where the South Sea Company had its board, a center of all kinds of money operations.

29 "The British Empire: India", in British Empire: The Map Room: India (1 Jun 2014), pp. 46-7, http:/ /www.britishempire.co.uk/maproom/india.htm, accessed 1 Jun 2014.

${ }^{30}$ Robert Young, Postcolonialism, An Historic Introduction (Malden, Massachusetts: Blackwell Publishers Inc, 2001), p. 308. 


\section{Mugijatna}

World War II made Britain almost bankrupt. Focus on domestic repair made Britain have no appetite to prolong its grasp in India. Britain couldn't do otherwise except grant independence to Pakistan and India.

\section{Rudyard Kipling}

Joseph Rudyard Kipling ${ }^{31}$ was born in Bombay (now Mumbay), 30 December 1865. His father, John Lockwood was a professor of architectural sculpture at the Sir Jamsetjee Jeejeeboy School of Art and Industry in Bombay. His Mother was one of the talented Macdonald daughters, one of whom was the mother of Stanley Baldwin, Prime Minister for three times (May 1923-January 1924, November 24-June 1929, May 1935-June 1937). When he was born, India had already become British Empire so that his parents identified themselves as Anglo-Indians which revealed their status as British colonials.

At the age of six, Kipling, together with his three years old sister, Alice (Trix), was sent to England in order to get education in England under the care of Captain and Mrs. Holloway in their house, Lorne Lodge. The couple used to take care of British children whose family lived in India. Kipling's life under the care of the family was often miserable. When visiting his Aunt, Georgiana, and her husband at their house, "The Grange", in London, Kipling felt as if he had lived in paradise.

In January 1878, Kipling was admitted to the United Services College, at Westward Ho! Devon, a school for boys prepared for British Army. At the end of the study at the school, Kipling failed to get scholarship from Oxford University and his father could not provide the supply for the fund. His father, then, obtained job for him in Lahore, Punjab, as an assistant editor of the Civil \& Military Gazette, a small local newspaper. In 1886, Kipling published his first collection of poems, Departmental Ditties. When the Editor of the newspaper was replaced by Key Robinson, Kipling got a more creative freedom, even he was asked to contribute short stories to the newspaper.

From 1885-1888, Kipling visited Simla every year to spend his leave there. Simla was a summer capital of British India, a well known hill station. There, he had a leisure time to write; when returning to Lahore thirty nine short stories appeared in the Gazette between November

${ }^{31}$ Rudyard Kipling, Something of Myself for My Friends Known and Unknown, web ed. (Adelaide: eBooks@Adelaide, 2014),https://ebooks.adelaide.edu.au/k/kipling/ rudyard/something/; "Biography of Rudyard Kipling”, Poem Hunter, http://www. poemhunter.com/rudyard-kipling/biography/, accessed 1 Jun 2014. 
1886 and June 1887. Most of these short stories were collected in The Plain Tales from the Hills, Kipling's first anthology of short stories which was published in Calcutta, in January 1888.

In November 1887, Kipling was transferred to The Pioneer, a larger newspaper in Allahabad. His creativity burst: in 1888 he published six anthologies of short stories, Soldiers Three, The Story of Gadsbys, In Black and White, Under the Deodars, The Phantom Rickshaw, and Wee Willie Winkie. But his stay with The Pioneer was short. In early 1889, after a dispute he was discharged. On March 9, 1889, he travelled to United States and then he traveled across Atlantic and arrived at Liverpool in October 1889. He wrote stories for many magazines and in the next two years published his novel, The light that Failed.

Kipling married an American woman, Caroline (Carrie) Starr Balestier, the sister of Wolcott Balestier, his collaborator in writing Naulahka (the correct spelling is Naulakha), on 18 January 1892 in London and then lived in Brattleboro, Vermont. He built a house in 10 acres of land and named the house Naulakha, after the name of a pavilion with Mogul architecture in Lahore Fort. During his stay in Brattleboro he wrote the first story of Jungle Books, The Days Work, The Even Seas (poems), and Captains Courage. In 1896, due to hostile political atmosphere in USA and a family dispute with his sister's brother, Kipling and his family moved to UK. His productivity continued unabated, in 1897 he wrote Recessional, in 1901 he completed Kim, in 1902 he completed Just So Stories.

For ten years from 1898, Kipling and his family annually made a winter visit to South Africa. There he stayed in "The Woolsack", a house on an estate owned by Cecil Rhodes. His fame as the Poet of the Empire made him received warmly by leading politicians in South Africa. In 1899 Boer War in South Africa broke out and Kipling wrote poetry to support British cause in the war. His experience in South Africa was reflected in some stories such as "The Captive," "A Sahib's War" and poems such as "Boots" and "Lichtenberg".

In the first decade of twentieth century Kipling's career rouse to the peak, in 1907 the Swedish Academy awarded him Noble Prize, the first English writer recipient of Noble Prize. He continued to write until a few years before his death on January18, 1936. He had two daughters and a son. One of his daughters died when she was only 6 years old because of pneumonia and his son died when he was only 18 in a war. His wife died in 1939, three years after him.

The short biography shows that Kipling lived in the era of the Al-Jāmi‘ah, Vol. 52, No. 1, 2014 M/1435 H 


\section{Mugijatna}

peak of British Empire. During this era, almost every Briton was an imperialist. As stated by Tom Noris, ${ }^{32}$ Britain is the "most profoundly and unalterably imperialist of society". So, Kipling's imperialism was no more than what his era had nurtured him. Since his childhood he had experienced his belonging to an imperialist society: his superiority over and his being different from native people.

\section{The Representation of Muslims in Kipling's Short Stories}

The first short story, "We Willie Winkie," is a story of a six years old and a quarter child whose full name was Percival William Williams, but he picked up the name, We Willie Winkie, in a nursery-book. His father, Colonel Williams, was the Colonel of the $195^{\text {th }}$ garrison and they lived in the cantonments. His father treated him under military discipline; when he was good for a week, his father gave him good-conduct pay and when he was bad he was deprived of his good-conduct badge. Generally he was bad. He liked to give a nick name to persons and the nick name would stick on the persons. He called Lieutenant Brandis "Coppy" and it became his nick name. One early morning, he saw Miss Allardyce, Coppy's future wife, taking a riding across the river, a territory of the Afghan, where he was not permitted to go into it, even Coppy had never gone there. He was told that at the hills across the river lived Goblins, even Bed Men. "Ever since that date it seemed to him that the bare black and purple hills across the river were inhabited by Goblins, and, in truth, every one had said that there lived the Bed Men". ${ }^{33}$ Her reason was to teach Coppy. "Coppy, in a tone of too-hastily-assumed authority, had told her over night that she must not ride over the river. And she had gone to prove her own spirit and teach Coppy a lesson". ${ }^{34}$

We Willie Winkie followed her, riding on his pony. At the foot of the hills, Miss Allardyce's Waler stumbled down and her ankle was twisted and could not move. We Willie Winkie set free his pony in order to go back to the garrison. Seeing the pony went home alone, the soldiers were stirred up to hunt for Wee Willie Winkie. He mustn't have fallen dawn from the pony. In the mean time the Bed Men appeared. On hearing Pustho ${ }^{35}$ they spoke, Wee Willie Winkie knew that they were only the

32 Parry, "The Content and Discontents of Kipling's Imperialism", p. 51.

${ }^{33}$ Rudyard Kipling, "Wee Willie Winkie", in Short Stories for English Courses, ed. by Rosa M.R. Mikels (New York: Charles Scribner’s Son, 1935), pp. 86-7.

${ }^{34}$ Ibid., p. 88.

35 The native language. 
natives. Wee Willie Winkie told them that he was the son of the Colonel of the regiment and asked one of them to run into the cantonments to tell what happened to Miss Allardyce, they would give them money. One of the men, instead, ordered the other men to carry him and Miss Allardyce away for ransom. Wee Willie Winkie realized now that "These were the Bed Men - worse than Goblin - and it needed all Wee Winkie's training to prevent him from bursting into tears" ${ }^{36}$ Wee Willie Winkie told them if they carried him and Miss Allardyce away, his regiment would come up in a day and killed them all. Another man, Din Mahommed, the dismissed groom of the Colonel, appeared and warned them that what the child had said was true. Two shots were fired by a look-out from up the hills, a warning to the men. When the look-out fired another shot, the men withdrew silently. The Colonel arrived to rescue Wee Willie Winkie and Miss Allardyce.

The summary shows how the native Muslims are described as Bed Men. The hills where they lived are described as bare black and purple hills inhabited by Goblins, a mischievous spirit or elf in the form an ugly-looking man. ${ }^{37}$ Wee Willie Winkie, the reverse, is described as "child of Dominant Race". ${ }^{38} \mathrm{He}$, who is only a child of six years old and a quarter, is very confident: "I am the Colonel's son, and my order is that you go at once. You black men are frightening the Miss Sahib. One of you must run to the cantonments and take the news that the Miss Sahib has hurt herself, and that the Colonel's son is here with her". ${ }^{39}$ The figure 1 of binary opposition shows how the Muslims are presented just as the opposite of the English colonizer.

The second short story, "The Story of Muhammad Din," a picture of a native Muslim child called Muhammad Din. ${ }^{41}$ Based on his inability to pronounce the sound "S", so that he says "Talaam Tahib," instead of "Salaam Sahib," the child may not be more than 5 years of age.

${ }^{36}$ Kipling, "Wee Willie Winkie", p. 90.

${ }^{37}$ Edward Lee Thorndike, The Thorndike-Century Junior Dictionary (London: University of London Press Ltd, 1942), p. 371.

${ }^{38}$ Kipling, "Wee Willie Winkie", p. 90.

${ }^{39}$ Ibid.

${ }^{40}$ Rudyard Kipling, "The Story of Muhammad Din", in The Plain Tales from the Hills: An Electronic Classics Series Publication, ed. by Jim Manis (Pennsylvania State University, 2013), pp. 161-3, http://www2.hn.psu.edu/faculty/jmanis/kipling/plaintales.pdf.

${ }^{41}$ The order of the words of the name is the reverse of Din Mahommed in "Wee Willie Winkie" (with different, correct spelling of Muhammad). 


\section{Mugijatna}

Figure 1: Binary Opposition between Wee Willie Winkie and the Native Muslims

\begin{tabular}{ll}
\hline \multicolumn{1}{c}{ We Willie Winkie } & \multicolumn{1}{c}{ The Native Muslims } \\
\hline Living in a cantonments (culture) & Living in hills and forest (nature) \\
\hline Good man & Bad men \\
\hline Brave and confident & Intimidating but, then, withdrew \\
\hline Superior & Inferior \\
\hline
\end{tabular}

His father, Imam Din, was the servant of the narrator. One day he asked the narrator, a Sahib, whether the narrator wanted his polo-ball, for his son, Muhammad Din wanted the polo-ball. The narrator didn't set particular store by it, but he wondered how the son had spied the ball which was put in the dining room. One day, when he returned from office half an hour earlier, he noticed the presence of the child in the dining room playing with something he discovered in the dining room and didn't notice the narrator's coming; it seemed that the child like to wander and play in the dining room when he was absence. His father ran hurriedly to the dining room to take his son and rebuke his son. The child broke into sobs. The narrator told Imam Din to tell his son that he, the Sahib, was not angry with him.

Since that day, Muhammad Din never played in the dining room anymore, instead he used to play about the compound, in and out of the castor-oil bushes, making a castle out of dust with the polo-ball halfburied in it. One night, when the narrator was strolling in the garden he unintentionally stumbled over the handiwork and ruined it. The next morning, the narrator came upon Muhammad Din crying softly to himself over the ruin. Someone had cruelly told him that the Sahib was angry with him for spoiling the garden and had scattered the rubbish. Muhammad Din effaced the trace of his dust-castle and when the narrator came home from office Muhammad Did said tearfully and apologetically, "Talaam Tahib". Through Imam Din, the narrator told Muhammad Din that he was permitted to amuse himself as he pleased. Muhammad Din rebuilt his castle, but the palace was never completed. Muhammad Din was ill and a week later died.

The summary shows how Muhammad Did is described as close to nature and culturally backward: "a tiny, plump figure in a ridiculously inadequate shirt which came, perhaps, half-way down the tubby stomach. 
The Representation of Muslims in Rudyard Kipling's Short Stories

Figure 2: Binary Opposition between The Sahib and Muhammad

\begin{tabular}{ll}
\hline \multicolumn{1}{c}{ Tha Sahib } & \multicolumn{1}{c}{ Muhammad Din } \\
\hline Master & Servant \\
\hline Living in the house (culture) & Playing in dust (nature) \\
\hline Well-dressed & Ridiculous \\
\hline Superior & Inferior \\
\hline
\end{tabular}

Figure 3: Binary Opposition between We Willie Winkie and Muhammad Din

\begin{tabular}{ll}
\hline \multicolumn{1}{c}{ Wee Willie Winkie } & \multicolumn{1}{c}{ Muhammad Din } \\
\hline His father is the Colonel of a garrison & His father is the servant of a Sahib \\
\hline Living in cantonments & Living in servants' house \\
\hline Riding (playing with) pony & Playing with dust under bushes \\
\hline Could stand crying when being & $\begin{array}{l}\text { Sobbing when his handiwork was } \\
\text { destroyed }\end{array}$ \\
intimidated & Inferior \\
\hline Superior & Nature \\
\hline Culture &
\end{tabular}

It wandered the room, thumb in mouth, crooning to itself as it took stock of the pictures". ${ }^{42}$ His proper play ground was not in the dining room, a cultured place, instead at dust on the garden. The figure 2 shows the representation of Muhammad Din as opposed to the representation of the Sahib.

The ridiculous and inferior representation of Muhammad Din is just the opposite of the representation of Wee Willie Winkie who is brave and confident.

The third short story, "The Recrudescence of Imray," is a story of a murder done by Bahadur Khan. Imray, a prospective young man working in a little Indian station, suddenly disappeared from the world. No search could find him. Three or four months later, Strickland, a policeman, rented the bungalow deserted by Imray. Strickland lived in the bungalow with his dog. The narrator of this short story visited Strickland short after Strickland had rented the bungalow and stayed in

${ }^{42}$ Rudyard Kipling, "The Story of Muhammad Din", in The Plain Tales from the Hills (USA: the Pennsylvania State University, an Electronic Classics Series Publication), p. 162, http://www2.hn.psu.edu/faculty/manis/kipling/[lain_tales.pdf, accessed 26 May 2014. 


\section{Mugijatna}

the bungalow for two days.

The house was haunted: there was "presence" at night. When the narrator told Strickland that he wanted to move from the house, Strickland asked him to stay on and see what this meant. Strickland saw the tails of two snakes appeared hanging between the ceiling cloth and the cornice of the wall and showed them to the narrator. Strickland climbed up to shake the snakes down and asked the narrator to break the back of the snake with cleaning-rod when the snakes fall down, but the snake tails drew up and disappeared. Strickland tore the ceiling cloth and put his head through the opening into the dark of the angle of the roof beam and found out something up there. Strickland thrust the ceiling cloth with a rod and the narrator saw a shape was pressing the cloth downward toward the table. Then the cloth ripped out from the wall, tore, and split, swayed, and shot down the shape to the table. One of the snakes got out from under the cloth and was bitten. Strickland covered the thing on the table with cloth. It was Imray's carcass.

Strickland and the narrator moved to another room, Strickland room, to discuss the matter. When Strickland took the bungalow, he took over almost all Imray's servants. One of the servants, Bahadur Khan, "a great, green-turbaned, six-foot Mohammedan,"43 came to remind Strickland to sleep. Strickland called him in and asked him when Bahadur Khan first came into his service. Bahadur Khan said that it was when Imray went to Europe secretly. Strickland told him that Imray had returned from his long journey and now he was lying in the next room waiting for his servants. Bahadur Khan was astonished. Strickland ordered Bahadur Khan to enter into the next room and followed behind him closely. Bahadur Khan saw the carcass of Imray and confessed that he had killed Imray. His reason was because Imray cast an evil eye upon his four years child (and patted his head) and then his child was bewitched and died. Strickland told him that he would be hung. Bahadur Khan let the half death snake bite his toe and an hour later he died.

The summary shows how Bahadur Khan, a Muslim, is presented as a cruel person. He believed in superstition and thought that his four years old child's death was due to Imray's casting an evil eye on him (and patting his head). When Strickland asked Bahadur Khan, "What said Imray Sahib ?" Bahadur Khan said, "He said he was a handsome

${ }^{43}$ Rudyard Kipling, "The Recrudescence of Imray", in The Works of Rudyard Kipling (New York: Black's Readers Service), p. 620. 
The Representation of Muslims in Rudyard Kipling's Short Stories child, and patted him on the head; wherefore my child died" ${ }^{44}$ Strickland told the narrator that it was "Simply and solely through not knowing the nature and coincidence of a little seasoned fever". ${ }^{45}$ It means that Bahadur Khan had misunderstood Imray's affection to his son due to his belief in superstition and not understanding the seasoned fever. He killed Imray when Imray was sleeping.

The representation of Bahadur Khan is just the opposite of the representation of Imray, Bahadur Khan's master, as shown in Figure 4.

The fourth short story, "Without Benefit of Clergy," tells the story of a young couple of an Englishman, John Holden, and a Muslim woman, Ameera. Her mother had sold Ameera to John Holden to become his wife for she had been left without money. They lived happily. When Ameera referred to herself as the slave of John Holden, for he had bought her from her mother, he instead called her "my queen," and then Ameera called him "my king". Ameera was pregnant and she was very happy; when the baby, which Holden inclined to resent, was born their loved would be more secured. So far, Ameera had always been jealous with the mem-log, white-women, and her mother told her that someday John Holden would return to his people. When the baby was born, John Holden's returning to his people was far-off.

The marriage was "without benefit of clergy"; the people at the club didn't know his marriage. And the drawback of the double life was manifold. The Government, considering that John Holden was a bachelor, ordered him out of station for a fortnight on a special duty, replacing a man whose wife was sick. Ameera encouraged him to go, she only asked him not to delay in returning. When the duty ended and he returned home the baby was born, a son, they named him Tota. Pir Khan, the watchman of the house told John Holden to slaughter two goats for the birth-sacrifice, Islamic fashion of celebrating the birth of babies. ${ }^{46}$ With the baby was between them, their happiness was perfect, even too perfect to endure. Suddenly, without warning, Tota grew sorrowful and complained of pains. It was a seasonal autumn fever. On the second day, the baby died.

Both Ameera and Holden were sorrowful, in particular Ameera, she blamed herself. Meanwhile, The Deputy Commissioner of Kot-

${ }^{44}$ Ibid., pp. 621-2.

${ }^{45}$ Ibid., p. 622. born child.

${ }^{46}$ This celebration is called 'aqiqa, that is slaughtering goats/sheep for a newly Al-Jämi'ah, Vol. 52, No. 1, 2014 M/1435 H 


\section{Mugijatna}

Figure 4: Binary Opposition between Imray And Bahadur Khan

\begin{tabular}{ll}
\hline \multicolumn{1}{c}{ Imray } & \multicolumn{1}{c}{ Bahadur Kahn } \\
\hline Sahib & Servant \\
\hline Prospective young man & Believing in superstition \\
\hline Affectionate & Cruel (Killing Imray) \\
\hline
\end{tabular}

Figure 5: Binary Opposition between Holden and Ameera

\begin{tabular}{ll}
\hline \multicolumn{1}{c}{ Holden } & \multicolumn{1}{c}{ Ameera } \\
\hline Master & Slave \\
\hline $\begin{array}{l}\text { Benevolent (treating Ameera as his } \\
\text { beloved) }\end{array}$ & $\begin{array}{l}\text { Dependent (treating herself as the slave } \\
\text { of Holden) }\end{array}$ \\
\hline Tended to resent the baby & Expected the baby very much \\
\hline $\begin{array}{l}\text { Rational (ordered Ameera to go to } \\
\text { Himalayas to avoid black cholera) }\end{array}$ & $\begin{array}{l}\text { Emotional (preferred to stay than to go } \\
\text { to Himalayas to contradict the mem- } \\
\text { log) }\end{array}$ \\
\hline
\end{tabular}

The marriage bore no fruit: Tota and Ameera died

Kumharsen who was staying at the club for a day told a tale that made Holden scared. A black cholera had been spreading and many people died. The English sent their wives to hills to avoid death. Holden ordered Ameera to Himalayas, but Ameera refused it. She was glad that the mem$\log$ went to the hills, she would stay instead. And Holden had been told to be ready to move to replace the man who would die. He was afraid of Ameera that she should die any time without his sight. When he received a telegram and saw Pir Khan breathless in the door he was not astonished. Ameera died and the landlord of the house would pull down the house, the Municipality would make a road across. So, Holden should move from the house where he had been master and lord.

The summary shows that John Holden loved Ameera and treated her as his beloved; he called her "my queen" to which Ameera responded "my king". But Ameera, who was aware of being sold by her mother to Holden, considered herself as Holden's slave. When she said that "It is not seemly for men to worship a woman," referring to white men's worshiping Maria, and Holden said, "Is it not seemly? Why didst thou not turn me from worshiping of thee, then?" Ameera said, "Thou a worshiper! And of me? My king, for all thy sweet words, well I know that I am thy servant and thy slave, and dust under thy feet. And I would not 
The Representation of Muslims in Rudyard Kipling's Short Stories

have it otherwise. See!" ${ }^{77}$ Even, in her dying she whispered to Holden's ear, "I bear witness "-- the lips were forming the words on his ear - 'that there is no God but - thee, beloved!" 48 She changed "Allah", in the syahadah, "I bear witness, there is no God, but Allah," with "thee, beloved". At the end of the short story, the narration says, "Then he thought that before he departed he would look at the house wherein he had been master and lord". 49 The sentence, "he had been master and lord," staples Holden's status as the master and lord of Ameera. Therefore the marriage bore no fruit: the son died and Ameera also died. The Englishman could not go as far as to marry a Muslimah.

The analysis clearly shows the binary opposition of the status of John Holden, the Englishman, as the colonizer, and Ameera, the native Muslim woman, as the colonized (Figure 5).

The representation of Muslim characters in the four short stories clearly represents a perception on Muslims (and - at the same time -Islam). It ranges from perceiving Muslims as bed men living in hills and forest ("Wee Willie Winkie") up to perceiving Muslims as the slave of the British ("Without Benefit of Clergy"). When the Muslims are presented as entirely living separately from the British, they are presented as living in hills and forest, the crudest stage of living when culture hasn't been known to them, the enemy of cultured British. When they are presented as living conjointly with the British, they are presented either as a cruel person as Bahadur Khan or as the slave of the British as Muhammad Din and Ameera.

\section{E. The Representation of Colonization in the Short Stories}

In all the representation, the British is not presented as the oppressor, instead as the benevolent master. Wee Willie Winkie told the natives that they would be granted with money if they informed the British that Miss Allardyce hurt herself and couldn't move. It was the native Muslims who were inimical; they would carry Miss Allardyce and Wee Willie Winkie for ransom. Muhammad Din was allowed to keep the polo-ball and played in the garden. It was Muhammad Din's own people who were cruel; they told Muhammad Din that the Sahib was angry with him, whereas he was not. Imray treated Bahadur's son

${ }^{47}$ Rudyard Kipling, "Without Benefit of Clergy", in Collected Stories, ed. by Rudyard Kipling (London: David Campbell Publisher Ltd, 1994), p. 167.

${ }^{48}$ Ibid., p. 178.

${ }^{49}$ Ibid., p. 180. 


\section{Mugijatna}

affectionately, praising Bahadur's son handsomeness and patting his head (an act of affection), but Bahadur Khan misunderstood them due to his supernatural belief and then killed Imray. Holden treated Ameera as his beloved wife; it was Ameera herself who humiliated herself as low as "dust under Holden's feet". But she couldn't do otherwise; she "must enact double subjugation". Her respect to Holden "was a total abjection of India as colonized and female," even she went as far as to utter "a deathbed blasphemy to her Islamic faith". ${ }^{50}$ In all the representation, Kipling, as Rushdie asserts, stands as "arrogant imperialist who thinks nothing of making a laughing-stock of native Indian characters". ${ }^{51}$

That is where colonization is represented in the short stories. It is a metaphor of Kipling's firm belief that "the British were helping to civilize and educate a previously 'savage' people. They were doing good deeds". ${ }^{52}$ It is “The White Man's Burden," as stated explicitly in his poem, “The White Man's Burden: The United States \& The Philippine Islands, 1899," which celebrated United State's invasion to Philippine. ${ }^{53}$ "Edward Said has proposed that Kipling studiously avoided giving us two worlds in conflict because for him 'there was no conflict ... it was India's best destiny to be ruled by England." 54 It disregards the fact the foreign occupation had ruined Islamic empire in India under Mogul Court sovereignty and ruined the economy and society of India as well. If in previous pages it has been described that by the end of $18^{\text {th }}$ century the British had established a military dominance that would enable them in the next fifty years to subdue all the remaining Indian states of any consequence, British occupation in India had also ruined local society and economy; Karl Marx describes the ruin as follows. "It was the British intruder who broke up the Indian hand-loom and destroyed spinning wheel". ${ }^{55}$ This breaking up the hand-loom and spinning wheel led to the breaking up Indian society and economy. ${ }^{56}$

Yet, as Rudyard Kipling believed that British occupation was

${ }^{50}$ Parry, "The Content and Discontents of Kipling's Imperialism", pp. 56-7.

${ }^{51}$ Lindgrén, "Plain Tales from the Hills as Emergent Literature", p. 104.

52 "Modern History Sourcebook: Rudyard Kipling, The White Man's Burden, 1899", Fordham University, http://legacy.fordham.edu/halsall/mod/kipling.asp, accessed 26 May 2014.

${ }^{53}$ Ibid.

${ }^{54}$ Parry, "The Content and Discontents of Kipling's Imperialism", p. 58.

${ }^{55}$ Karl Marx, "The British Rule in India", in Karl Marx and Friedrich Engels, On Colonialism (Moscow: Progress, 1968), p. 36.

${ }^{56}$ Ibid., p.37. 
The Representation of Muslims in Rudyard Kipling's Short Stories

beneficial to India, Karl Marx also believed that even though British occupation over India was "sickening $[\ldots]$ to human feeling to witness those myriads of Industrious patriarchal and inoffensive social organizations dissolved into their ruins, thrown into a sea of woes, and their individual members losing at the same time their ancient form of civilization and hereditary means of subsistence," ${ }^{57}$ British colonization over India had caused social revolution on Indian's old culture, which was barbarous, into a better condition. "Then, whatever bitterness the spectacle of the crumbling of an ancient world may have for our personal feeling, we have the right, in point of history to exclaim with Goethe: 'Solite diese Qual qualen, / Da sie unsre Lust vermehrt, / Hat nicht Myriaden Seelen/ Timurs Herrschaaft aufgezehrt?" 58 So, if Karl Marx who criticized capitalism believed that British colonization over India was beneficial to India, we can only say that Kipling's imperialism in his short stories is not more than the spirit of his age dictating him.

\section{F. Concluding Remarks}

The representation of Muslim characters in the four short stories clearly represents colonial/imperialist perception on Muslims (and - at the same time -- Islam). It ranges from perceiving Muslims as bed men living in hills and forest up to perceiving Muslims as the slave of the British. In all the representations, the British is not presented as oppressor, instead as benevolent master. That is where colonization is represented in the short stories. It is a metaphor for Kipling's firm belief that the British were helping to civilize and educate a previously "savage" people; it disregards the fact that British colonization over India had ruined Islamic empire in India under Mogul Court sovereignty and ruined Indian economy and society organization as well.

Those kinds of representation on Muslims are abundant in Western publications. The representations have created stereotypical perception on Muslims (and Islam) held by many Western people until today. Cartoon on the prophet produced by Danish cartoonist in 2005, anti-Islam film, Fitna, produced by Geert Wilders, a Dutch politician, in 2008, and caricatures on the Prophet published in French's weekly, Charlie Hebdo, in 2012 all demonstrate the perception. We need to study those kinds of presentation in order to understand how Western's colonialism/

${ }^{57}$ Ibid., p. 38.

${ }^{58}$ Should this torture then torment us/ Since it brings us greater pleasure?/ Were not through the rule of Timur/Souls devoured without measure?; Ibid., p. 39. 
M. Mugijatna

imperialism mindset over Muslim and Islam still persists today. Hopefully, this understanding will lead to a better interaction between Muslims (Islam) and Western people. 
The Representation of Muslims in Rudyard Kipling's Short Stories

\section{BIBLIOGRAPHY}

“A Reading of Kipling's 'Muhammad Din”, https://sites.google.com/ site/jimmyastacio/apostcolonialreadingofkipling $\% 27 \mathrm{~s} \% 22$ muham mad, accessed 26 May 2014.

Albrecht, Monika, "Postcolonialism, Islam, and Contemporary Germany", Transit, vol. 7, no. 1, 2011, pp. 1-25.

"Biography of Rudyard Kipling", Poem Hunter, http:/ / www.poemhunter. com/rudyard-kipling/biography/, accessed 1 Jun 2014.

Brown, Ryan, "The British Empire in India", Ohio: AshbrookAshland University, 2010, http://ashbrook.org/wp-content/ uploads/2012/06/2010-Brown.pdf.

Fiske, John, Cultural and Communication Studies, 3rd ed., ed. by Idi Subandy Ibrahim, trans. by Yusal Iriantara, Yogyakarta: Jalasutra, 2006.

Kipling, Rudyard, "Wee Willie Winkie”, in Short Stories for English Courses, ed. by Rosa M.R. Mikels, New York: Charles Scribner's Son, 1935.

----, "Without Benefit of Clergy", in Collected Stories, ed. by Rudyard Kipling, London: David Campbell Publisher Ltd, 1994.

----, "The Story of Muhammad Din", in The Plain Tales from the Hills: An Electronic Classics Series Publication, ed. by Jim Manis, Pennsylvania State University, 2013, http://www2.hn.psu.edu/faculty/jmanis/ kipling/plain-tales.pdf.

----, Something of Myself for My Friends Known and Unknown, web ed., Adelaide: eBooks@Adelaide, 2014, https://ebooks.adelaide.edu. au/k/kipling/rudyard/something/.

----, "The Recrudescence of Imray", in The Works of Rudyard Kipling, New York: Black's Readers Service.

Lindgrén, Inna, "Plain Tales from the Hills as Emergent Literature", Nordic Journal of English Studies, vol. 6, no. 2, 2007, pp. 83-104.

Majelis Ulama Indonesia (MUI) Kota Surakarta, Kritik Evaluasi \& Dekonstruksi Gerakan Deradikalisasi Aqidah Muslimin di Indonesia, Surakarta: Al Maktab Publication, 2011.

Marshall, Catherine and Gretchen B. Rossman, Designing Qualitative Research, 2nd ed., California: Sage Publications, 1995.

Marshall, Peter, "The British Presence in India in the 18th Century", $B B C$, http://www.bbc.co.uk/history/british/empire_seapower/ 


\section{Mugijatna}

east_india_01.shtml\#top, accessed 26 May 2014.

Marx, Karl, "Anglo-Persian War", in Friedrich Engels and Karl Marx, On Colonialism, Moscow: Foreign Languages Publishing House, 1968.

----, "The East India Company - Its History and Results", in Karl Marx and Friedrich Engels, On Colonialism, Moscow: Progress, 1968.

----, "The British Rule in India", in Karl Marx and Friedrich Engels, On Colonialism, Moscow: Progress, 1968.

"Modern History Sourcebook: Rudyard Kipling, The White Man's Burden, 1899", Fordham University, http://legacy.fordham.edu/ halsall/mod/kipling.asp, accessed 26 May 2014.

Moosavinia, Rahim, "Texts and Politics: Postcolonial Revaluations of Two British Classics", Journal of Teaching Language Skills (JTLS), vol. 3, no. 3, 2011, pp. 67-82.

Nöth, Winfried, Handbook of Semiotics, Indiana Polis: Indiana University Press, 1995.

Parry, Benita, "The Content and Discontents of Kipling's Imperialism", in Space and Place: Theories of Identity and Location, ed. by Erica Carter, James Donald, and J. Squires, London: Lawrence \& Wishart, 1993.

Said, Edward W., Orientalisme, trans. by Asep Hikmat, Bandung: Penerbit Pustaka, 1978.

Sayyid, S., "Empire, Islam and the Postcolonial", in MnM Working Paper No. 9, Australia: University of South Australia, 2012, http://www. unisa.edu.au/Documents/EASS/MnM/working-papers/sayyidempaire-islam-postcolonial.pdf, accessed 1 Jun 2014.

"The British Empire: India", British Empire: The Map Room: India, http:/ / www.britishempire.co.uk/maproom/india.htm, accessed 1 Jun 2014.

Thorndike, Edward Lee, The Thorndike-Century Junior Dictionary, London: University of London Press Ltd, 1942.

Thwaites, Tony, Lloyd Davis, and Warwick Mules, Tools for Cultural Studies: an Introduction, Melbourne: Macmillan Education Australia PTY LTD, 1995.

Wellek, Rene and Austin Warren, Theory of Literature, New York: Harcourt, Brace \& World Inc, 1956.

Young, Robert, Postcolonialism, An Historic Introduction, Malden, Massachusetts: Blackwell Publishers Inc, 2001. 